\title{
Integrating perspectives: proposal for the analysis of work as a multifaceted phenomenon
}

\author{
Renato Koch Colomby, Andrea Poleto Oltramari and \\ Maria Beatriz Rodrigues \\ Federal University of Rio Grande do Sul, Porto Alegre, Brazil
}

Received 12 February 2017 Revised 21 May 2017

\begin{abstract}
Purpose - The purpose of this paper is to analyze the phenomenon of work from eight different and subsidiary perspectives: physiological, cultural, spiritual, ideological, economic, political, legal and psychosocial.

Design/methodology/approach - This study is based on an exploratory quantitative survey with a probability sample composed of 407 cases. The bibliographic review resulted from several readings about the phenomenon of work and the impacts arising from these different perspectives.

Findings - The analysis of the data collected confirmed that the meaning and the sense of work are multifaceted. The authors also found that work is an important source of reflection and learning in people's life. The research instrument promoted thinking and analysis of the participants' careers. The research process resulted in mutual and interactive learning of investigators and investigation.

Research limitations/implications - The data collection came from a single source: a written questionnaire. This limits the scope of the data and raises interpretative discussion concerning the contents of the answers. For future reference, the authors suggest to complement it with different techniques of data collection, associating qualitative and quantitative approaches.

Practical implications - The main contributions of the paper are, on the one hand, the effort of synthetizing and recording eight different categories of analysis of the multiple and possible meanings of work, which were elaborated using the available literature, and on the other hand, to understand and analyze those categories using the perception of a numerically meaningful sample of the public, coming from different backgrounds.

Social implications - The purpose of this paper is to propose a guideline for future studies so that they could choose with increased awareness the initial perspectives at the basis of the analyses. This study could encourage continuity and provide greater incentives on this increasingly relevant subject.

Originality/value - After analyzing the data, it was acknowledged that work cannot be seen from a single perspective, but it must be viewed in its multifaceted character and sense. The published material on the meanings of work usually focuses on specific professions and careers, the authors argue that this fact limits the scope of perspectives and interpretations of the phenomenon.
\end{abstract}

Keywords Labour, Meaning of labour, Sense of labour, Labour perspectives, Labour trajectories

Paper type Research paper

\section{Introduction}

The authors from different theoretical lines agree on one point: work is crucial in society. According to Mercure and Spurk (2005, p. 7), "work can never be ignored for its presence, its strength and the space it occupies." We could also quote Mow (1987) and Morin (2001) in a functionalist and managerial perspective and the authors like Antunes (2002a), Dejours (2004), and Cattani and Holzmann (2011) in a critical and non-functionalist perspective.

Work is the core of wealth production, individuals' identity construction and collective behavior outlining. Though some authors announce the end of work for countless reasons, including the use of technology or the drastic changes in the market and labor relations,

(C) Renato Koch Colomby, Andrea Poleto Oltramari and Maria Beatriz Rodrigues. Published in Revista de Gestão. Published by Emerald Publishing Limited. This article is published under the Creative Commons Attribution (CC BY 4.0) licence. Anyone may reproduce, distribute, translate and create derivative works of this article (for both commercial and non-commercial purposes), subject to full attribution to the original publication and authors. The full terms of this licence may be seen at $\mathrm{http} / /$ creativecommons.org/licences/by/4.0/legalcode

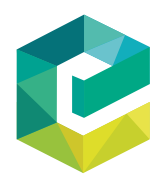

Revista de Gestão Vol. 25 No. 1,2018 pp. $65-83$ 
REGE 25,1

over the last decade (Antunes, 2002b; Rifkin, 2007), whereas others defend that these deep transformations make bringing the world of labor back into the center of research and reflection imperative (Cattani and Holzmann, 2011). Workers have collectively shared feelings regarding the construction of their tasks. Such feelings are marked by ideologies that are associated with and derived from the social, economic, political, legal, cultural and spiritual perspectives they are inserted in. Thus, these elements influence meanings and senses associated with work.

Work senses have been some of the most relevant themes in academic production and require additional investigative effort. Spinelli-de-Sá and Lemos (2015) stated that there are still many gaps about this theme to be filled in the Brazilian context. Several studies are being carried out on meaning and senses of work; however, future studies, with special attention to the phenomenon and analyses under different perspectives, respecting the theme's multifaceted character, are necessary (Rodrigues and Barrichello, 2015). It is necessary to stimulate different perspectives on the meanings of work for the individuals, mainly considering the moment of intense transformations in society and economy (Bastos et al., 1995).

Dourado et al. (2009, p. 352) rescued four instances of work and affirm that those "are the interconnections between economic, political, ideological and psychological instances that influence the individual phenomenon of attributing sense to the labor action." The intention of this paper is to go further in this point and it proposes eight perspectives to analyze the phenomenon of work: physiological, cultural, spiritual, ideological, economic, political, legal and psychosocial.

To do so, this paper used a survey method, contributing to increment quantitative research works, which present 14 percent of the publications on the theme from 2000 to 2015, according to a study carried out by Spinelli-De-Sá and Lemos (2015). In addition, the aim of this study is to obtain a panoramic view of the phenomenon of work, going in the opposite direction from most research works, which, according to the same authors, are directed at specific and less conventional work situations and categories.

After this introduction, we present the review on the literature about the different perspectives of work. The next section refers to the methodological procedures; the fourth part is dedicated to the analysis and discussion of the results and the fifth part presents reflections on this theme. Finally, the last section is dedicated to final considerations.

\section{The different meanings attributed to work}

Problematizing the theme "work" from eight different perspectives leads to a ground of historical analysis, provided it follows relevant social changes. It is necessary to rescue several authors to understand those multiple perspectives, as well as to elaborate a synthesized plan. However, the already-consolidated discussion on the work process in different production models or the consequent passage from Fordism to post-Fordism has been avoided. The focus relied on the theoretical discussion about work nowadays, once the subjects investigated live it currently. Thus, the theoretical review goes from authors who studied the themes after the productive restructuring of the 1990s, the consolidation of the so-called "post-Fordist" production and work model, and characteristic of a globalized and flexible society.

Since the 1990s, several authors have been proposing to discuss work from profound social changes, which have affected the way of working and labor relations. The contemporaneous outbreak factor can be considered the petrol crisis in the 1970s and the consequent termination of treaties, such as the Bretton Woods from 1944, that kept currencies from ally countries linked. The consequent recession, associated to a gradual exhaustion process of the Fordist model, resulted in a great need of revising the production world: organization size, command lines, quality, productivity, among others. So, the post-Fordism is born, as well as its inherent need of making work and markets flexible. 
On the one hand, these changes can be understood as necessary for the period, but then, they were taken to extremes by several economic interests. Nowadays, work is flexible, disposable, and replaceable by individualist technology, marked by the fast obsolescence and the continuous need of education and refinement (Rodrigues, 2014).

Several concepts fit into these contemporaneous characteristics of work. Maybe the first author to broadly translate them was Sennett (2009), who approached the corrosion of the character in the flexible man and, not limiting himself to this concept, attentively analyzed the new capitalist order. Bauman $(2005,2007)$ had also understood the changing times, he called them liquid, to the point of denouncing the wasting of lives (wasted lives), which stems from the human inability to follow the fast social changes.

Other authors named current days as second (Beck, 2000) or high modernity (Giddens, 2002), characterized by a widely globalized world, with new moral values and ephemeral relations. Though not directly addressing the theme "work," these last authors provide a broad view on social transformations, which forged the changes in the world of labor over the past decades, like for instance, the crescent competitiveness arising from globalization, the lack of safety from an ever more global and less local world, that is, a society of risks, to quote Beck (2006).

According to Fontoura and Rocha-De-Oliveira (2014, p. 2), "work is a complex activity, difficult to conceptualize for the diversity of objects, events and situations it involves and for the diversity of meanings it assumes in different historical contexts." Cattani and Holzmann (2011, p. 7) defined the phenomenon as follows:

Work, as a vital activity that ensures satisfaction of production and reproduction needs of any human grouping, is a universal practice and a social realization that defines multiple conditionings and possibilities. Its concreteness, distinctively materialized in each historical context, can be configured in social relations marked, on one side, by the effects of power, by domination and exploitation, presenting negative symbolic meanings and forming a complex thread of contradictorily arranged. On the other hand, it could express cohesion, consent and pleasure by creating a collective work, aiming at overcoming the limits imposed by nature.

For Castel (1998), work is configured as an economic, psychological, cultural and symbolic reference in structuring existences, like an enrollment support in social structure. Starting from these ways of understanding and conceptualizing the current work, we selected different concepts from the authors who approached the theme from eight supplementary categories, which guide this article's discussion.

From the physiological perspective, along with cultural, political and legal aspects, one can discuss the problems faced by injured or sick workers, who no longer comply with the excellence standards required by organizations (Schlindwein, 2013). Likewise, aging could be analyzed from the physiological point of view. With the increase in life expectancy, the natural aging process results in impacts on the professional life of workers, who experience physical alterations, for example, loss of control over the body (Duncan and Loretto, 2004; Lima et al., 2012).

In this sense, current discussions about the social welfare reform, which would extend the minimum age required for retirement, are factors to be considered in work relations and its physiological, legal, social and cultural aspects. This makes us think about aging, not only in biological terms, but also in cultural - that is, how different social groups (de)value their elders (Locatelli and Dos Santos Fontoura, 2013). The same can be said about the gender division of work, as throughout history, different labor activities remain considered more fit for men and/ or women (Hirata and Kergoat, 2007). It is stressed that all societies define such distinction with more or less rigidity and exclusiveness; however, the distinction between male and female activities regards social production and gender conception and gender itself (Holzmann, 2011). We can notice, for the discussion so far, that work analysis perspectives overlap, which makes it difficult to try to clearly define one without referring to other(s). 
REGE 25,1
The cultural point of view cannot be underestimated in work-related discussions. Professions loose or gain prestige over time, according to perceptions, knowledge and beliefs cultivated by a society. In different locations, or period of history, professions were and are still considered as deviant from what is valued or accepted by given social group (Becker, 2008). According to Laner (2005), work, in its relational aspect, becomes cause and consequence of a culture and its respective social formations. Thus, work is molded by and molder of culture and these aspects transcend time - influencing future generations - and space, impacting the worker's private life.

Another factor that influences how work and its senses are perceived is spirituality. Krishnakumar and Neck (2002) stressed creativity, honesty, personal realization and commitment, as benefits of the incentive to spirituality in the work environment, contributing to increment in the organizational performance. However, spiritual culture can be realized personally and collectively, inside or outside religious institutions. Therefore, religion can overlap to the spiritual perspective of work, as said by Marques (2010). When stating that both are very close in their aspirations, feelings and experiences involving the search for transcendence and the interest by the holy.

Specifically regarding religion, it is stressed that the bible connected work to sin and punishment when Adam was expelled from Heaven and, to be punished, was submitted to work. Until then, work only had the sense of sharing, maintaining and cultivating God's work. After then, Augustine of Hippo associated work with a voluntary action arising from Divine order (Laner, 2005; Bendassoli, 2009).

For Mises (1995, p. 593), "religious activity requires place for the ceremony and structuring; sports require several devices and apparatus, instructors and coaches." However, his vision of work is mainly economic because according to the author, "all these things pertain to the orbit of consumption." In addition, "people work because they want to collect the rewards of work," i.e., its corresponding remuneration or immediate gratification. The economic approach is very recurrent in studies in work, by means of employment and unemployment statistics, absences, salary ranges, turnover, education, isonomy and many others that serve as basis for the discussion of many authors in the field. In this sense, the economic approach is close to legal.

It is stressed in the legal approach of work that the social rights in Brazil were, until not long ago, connected to the subject's work status (Carreteiro, 2006). Tozatto (2009) corroborated this thought, highlighting that citizenship and social rights in Brazil are, mistakenly in his opinion, though, only connected to remunerated workers. This demonstrates the importance of work in society from the legal, juridical and citizens' and workers' rights point of view. With respect to changes in these social rights, which were processed in the country, especially after the 1988 Federal Constitution, Cattani and Holzmann (2011, p. 08) stressed some counterpoints:

The typical wage labor, formalized, guaranteeing labor rights, gave rise to procedures regarded as innovative. However, under flexible forms of employment relationships, these resulted in insecurity, which at its turn resulted in lower direct (wages) and indirect (education, health and pensions guaranteed by the State) earnings.

According to Morin (2001, p. 12), the set of paid activities in an "economically organized system" will be named work and this conception "almost necessarily implies the notion of wage and the individual's consent in allowing someone else do dictate his/her work conditions." The same author, in stating that "work can be defined in several ways," warns that "when we study work, it is important to know what individuals think when they talk about it." These reflections emphasize the importance of the ideological dimension of work, namely, how each person sees the world reflected in how they understand the phenomenon. 
We could say that the ideological dimension in work perception is present in all other dimensions, altering the way the individual and social groups understand this phenomenon. Ideology exercises a sort of standardization of the desires and behaviors of individuals sharing it (Horochovski and Taylor, 2001). Thus, "the way work is seen and its meaning for people are strongly influenced by the ideology orienting them" and for that reason, this phenomenon ends up being seen as, among others, a blessing, a punishment or a way to accumulate capital (Dourado et al., 2009, p. 353).

When regarding a socially and economically organized system, we address the labor policy perspective, provided this is a great social organizer (Barel, 1982). According to Presthus (1962), ours is an organizational society and, likewise, Etzioni (1964, p. 1) pointed out that we live in a world of organizations, that is:

$[\ldots]$ we are born in organizations, we are educated by organizations, and most of us spend a lot of time of our lives working for organizations. We spend much of our time paying for leisure, playing and praying in organizations. Most of us will die in an organization, and when the time comes for the funeral, the largest organization of all - the State - must grant official permission.

Thus, organizations are spaces to perform activities and personal goals, being work the vehicle of subject construction from a multidisciplinary perspective, which takes into account social, psychological, economic factors, among others. Thus, work's psychosocial dimension is included. According to Dejours et al. (2012), work is an important means for satisfying the social and psychological needs, thus becoming an essential factor of sense to human life. The meaning of work is social because it is shared by a set of people; and psychological, because it involves subjective issues that relate to individuals and their personal stories (Souza and Tolfo, 2009).

The singular and/or individual and the plural and/or collective do not annul one another. Through the collective agreements and standards, a part of subjectivity is given up to co-exist cooperatively for work. However, for this process to be possible and endowed with all sense that work represents in people's lives, it is necessary to recognize and respect the subjectivity of this phenomenon (Dejours, 2004). It is realized that much of our life is related to some aspect of work starting from the education and training to exercise a profession to the late time of retirement (Laner, 2005).

By presenting the eight perspectives proposed (cultural, spiritual, physiological, economic, legal, ideological, political and psychosocial), it is confirmed that the phenomenon work presents a multiplicity of meanings, and can be analyzed from different, complementary and often overlapping each other, points of view. It is stressed that this is only one form of analysis, that other views can be used to understand work, and that this literature review does not aim at limiting views on the theme. On the contrary, its aim is to search new ways to understand it and advance in research works addressing the problem. Figure 1, therefore, presents a summary of the reflections observed.

Just like Bendassoli (2009), the other authors believe that the meaning of work could be considered plural as it is made of different influences, while none of them takes the priority on the others. Figure 1 represents the categories compiled, synthesized and recorded by the authors. The aim of this theoretical reference was to organize, in possible sets, the existing literature on the subject.

\section{Methodological procedures}

This study was conducted using a predominantly quantitative approach and was characterized as an exploratory survey. On the decisions relating to the study, it is important to highlight the search for respondents with diverse backgrounds, i.e., people from different backgrounds, cultures, ages and professions. The works published about senses and meanings of work, as a rule, have focused on certain professions and careers, a fact which limits perspectives and interpretations of the phenomenon. 


\section{REGE}

25,1

\section{0}

Figure 1.

Perspectives of work

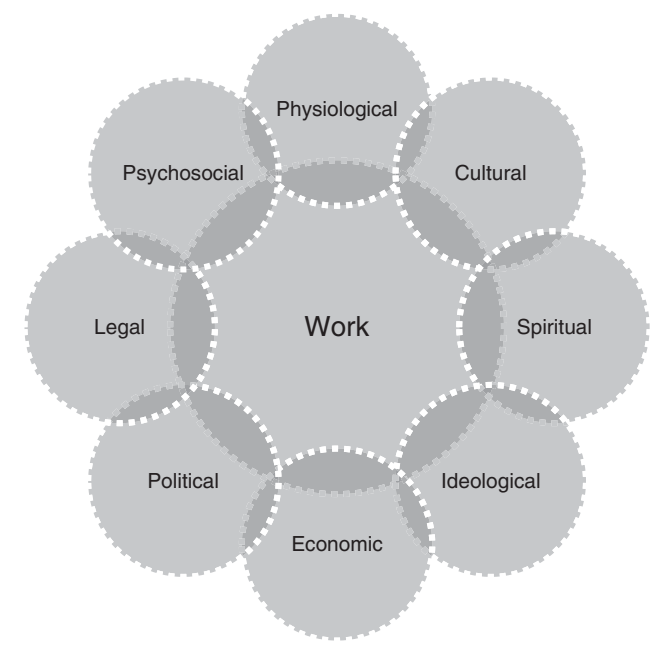

Source: Prepared by the authors

The survey also included some open-ended questions and a free space left at the end of the form, where the respondent was invited to freely write what they wish, in order to contribute with more data they judged relevant to this investigation. Therefore, qualitative analyses were connected to quantitative analyses throughout the paper, in order to encourage reflections by the readers.

Considering an undetermined number of readers, an infinite universe was used. The sample used is composed of 407 cases, presenting error margin of 4.8 percent with a trust interval of 95 percent. The formula used for calculating the probabilistic sample, of infinite universe, was $n=4 . p . q / \mathrm{E}^{2}$. The procedures adopted for statistical analysis were absolute and as follows: relative frequency, averages, variance test, i.e. ANOVA and one-way, in which it established the acceptance of differences of up to 0.05 significance, Student's " $t$ " test and Cronbach's scale reliability, with $\alpha$ higher than 0.60 .

The research instrument, a questionnaire with four open-ended and 22 close-ended questions, was created by the authors, based on the theoretical references and on the discussions based on several studies on the phenomenon work. To approach respondents, in addition to an initial registration with e-mail, gender, age, place of residence, educational level, profession, specific invitations to participate in the survey, which afterwards reflected in other subjects, were sent.

The survey questions were measured by interval scale, in level of concordance from 1 to 5 . Also, the script included eight categories (physiological, cultural, spiritual, economic, legal, ideological, political and psychosocial), with two to three questions each, presented in different blocks in the survey form. Questions followed a five-point Likert-type scale, presented with possibilities of answer from fully agree to fully disagree. The questionnaire was validated during more than two months, with over 400 respondents.

The area of study was international and aimed at a better dissemination of research and access to respondents, and data collection took place predominantly via social networks. With this technique of data collection, the chances of participation can be reduced if the audience has been extensively used for other researches; not enough access time or internet connection instability; or when the forms are too long and tiring. So, the aim was to create a series of questions in which the topic and proposed goals were covered but, at the same time, it was not exhausting to complete. The software used was the Statistical Package for 
Social Sciences (SPSS), which made it possible to compare two different groups of respondents, by social media and electronic mail, and it was noticed that the origin of sources did not interfere with the answers.

The journey was long, since deciding to carry out a survey until its disclosure. Over 69 days, over 20 shares in a broad social network were necessary to reach the most diverse respondent's profiles. The open-ended questions had their answers grouped and categorized. For instance, occupations described as administrative assistant or just "adm." were grouped under the sole naming of "administrative." The first step was carried out manually to, then, organize the templates using the statistical software SPSS. The same procedure occurred with categorizing occupations like, for instance, teacher and professor, which were sorted as "Education."

Thus, the categories were built based on the answers, which included the area of acting, professions, occupations and some categories ended up having more than eight related professions, which generated a caption to allocate them.

\section{Data presentation and analysis}

\subsection{Sample characterization}

The sample of this study is composed of 66.3 percent female respondents and 33.7 percent male respondents. We registered the participation of respondents residing in more than a dozen units of the Federation (Rio Grande do Sul, Ceará, Distrito Federal, Espírito Santo, Goiás, Minas Gerais, Mato Grosso do Sul, Mato Grosso, Piauí, Paraná, Rio de Janeiro, Santa Catarina and São Paulo) and abroad (Angola, Australia, Canada, France and Portugal). Of the total respondents, 98.78 percent claim to currently live in Brazil and the rest is distributed around the other countries listed. As for age distribution in the sample, 26.3 percent have up to 25 years of age; 41.8 percent from 26 to $35 ; 20.4$ percent from 36 to 45 ; 9.6 percent from 46 to 55 ; and 2 percent have age over 55 years. For analysis purposes, we gathered the data of these last two categories, getting a single category of more than 45 years.

As for education, 27.3 percent have incomplete higher education and 18.2 percent have already completed this step of their training. In total, 41 percent of the respondents checked "Post-Graduation" option (specialization, master, doctorate or post-doctorate), which they may be studying or have finished. In total, 13.5 percent of the sample has incomplete elementary school to complete high school, including technical training and others. On life trajectory and insertion in the labor world, 74.9 percent is currently working, 19.2 percent has worked and 5.9 percent answered that they have never worked or prefer to classify their professional history differently. As for the type of activity, 57.7 percent reported being employed; 23.8 percent informal; 9.6 percent entrepreneurs; and 8.8 percent did not answer. The area of practice that represents the largest share in the survey is education, with 27.3 percent, followed by administrative, with 24.6 percent.

Most of the respondents (79.4 percent) had access to the questionnaire through social networks. The answers were received between February and April 2016.

\subsection{Indicators' concordance degree}

The averages of the measured dimensions are presented as follows: the proposed study presented $\alpha$ equal to 0.8 , which defines the range as reliable, in Cronbach's scale reliability test.

Of statements presented in the form, those related to cultural perspective were the ones that had higher level of concordance, from the respondents' perspective (Table I). The average in cultural dimension was 4.44. Among the items evaluated, the one that showed the highest average concordance (4.50) was: cultural factors can still influence the perception of professions, which are still seen as male- or female-fit. Analyzing work from the cultural perspective can imply on the demystification of matters related to 
REGE 25,1

Cultural perspective gender division of work, i.e., inserting women and men in the labor market in professions perceived as specific or more indicated for a specific gender. In this statement, the respondents agreed with the presence of dichotomy in society, between what is socially seen and built, as being male- and female-fit professions, reinforcing stereotypes and stigmas on occupations. Participants also highly agree that professions can have their prestige affected over time, or that the phenomenon of work may have modifications in the way it is perceived and executed, depending on the culture of a particular region. The meaning of "prestige" could have also been discussed among the respondents and it was emphasized that this definition could also have variations depending on time and location in which it was questioned. One of the respondents voluntarily supplements what has been exposed so far:

My relationship with work completely changed two years ago, when I moved to Quebec. Now I have control of my life, I work with what I like, I have more than one job. My relationship with work went from obligation, like meeting timetables because I had to solve problems.

The average perceived for the economic dimension (Table II) was 3.79, which demonstrates less concordance of respondents, compared with the cultural perspective. When the respondents refer less concordance with the statements - "a job can be just a means of survival" and "a job can have acquiring new things as its sole purpose" - they are also saying that a job can have so many other meanings and goals, which agrees with this research. Among the items evaluated, the one that showed the highest average concordance (4.42) was: having a wage is a way to feel safe, organize life, project a future and have the expectancy that your children will climb up the social ladder. Cattani and Holzmann (2011) argued that, especially after the Second World War, wage labor has become a valuable source of safety for workers. The data show that under this perspective, attention and importance are given to security and stability, especially for the family. It is interesting to note that the psychosocial perspective can derive from the economic perspective, since working is also the satisfaction of individual and social needs, such as the sense of organization of life.

Resuming the theoretical discussion on the evolution of post-Fordist forms of organization and the increasing flexibility of the labor market, even though respondents highly agreed with the item about the safe work, we know that the market does not provide it in the same proportion as it did in the post-war period. This is a very sensitive

Statements

Average

Cultural factors can still influence the perception of professions, which are still seen as male- or female-fit

Some professions may win or lose prestige over time

4.50

The way how work is performed or understood may be different depending of which region/city/country a person lived in

Overall average of this perspective

4.34

4.44

Having a wage is a way to feel safe, organize life, project a future and have the expectancy that your children will climb up the social ladder

Table II.

Overall average of this perspective 
aspect of the current jobs, which concerns not only the social, economic and psychosocial dimensions, but also psychological dimension, considering the importance of health at work. Maybe in many cases, the answers refer to wishful thinking more than they refer to reality.

In the spiritual dimension, the general average obtained was 3.93 (Table III). Among the items evaluated, the one that showed the highest concordance average (3.94) was: religion can change the way someone perceives the job, which was really close to the average obtained (3.92) for the statement that spirituality influences work. Spirituality here is understood as a way of connecting with the world, which may or may not include religion. One of the respondents, who fully agreed with the statements related to spirituality, pointed out that "someone who is optimistic or looks at life positively, tends to see work beyond financial or professional security." Another respondent questioned: "do those more religious tend to follow careers that lead them to help people who need 'more' care, like doctors, nurses, educators, policemen, to sum, professions connected to health, safety and education?"

Under the physiological perspective, as per Table IV, the average perceived was 3.75 . Among the indicators evaluated, the one presenting the highest concordance average (3.94) was: a disability or chronic illness can change a person's reality of work. When analyzing the physiological dimension, we must pay attention to the complexity of the disease and the lack of control over the body, which can affect the employee. In addition, the fear of aging also concerns the physiological perspective (Lima et al., 2012). Sex/gender relation, attributed to some occupations, which obtained an average of 3.44, will be deepened further in the text, when we will discuss the professions aimed by the respondents, as more male- or female-fit.

Under the ideological perspective, the average perceived was 4.22 (Table V). Among the indicators evaluated, the one presenting the highest concordance average (4.54) was: the way a person sees the world can reflect in the way he/she perceives the job. People's wishes and their relationship with work are strongly influenced by their ideological perspective, i.e. how they understand the world reflects on the way they work. The polarization between the socialism/communism and liberalism/capitalism was a way to identify the respondents' understanding about the political-ideological issue. One of the respondents inferred that "class fights will always exist and constantly mutate in the capitalist system." Another respondent states that "work may have a different sense for those who tend to become entrepreneurs." These opinions corroborate with the claims of the ideological category.

\begin{tabular}{lc}
\hline Statements & Average \\
\hline Religion can change the way someone perceives work & 3.94 \\
Spirituality, when consider one's way of connecting with the world, influences work & 3.92 \\
Overall average of this perspective & 3.93
\end{tabular}

Source: Prepared by the authors

Table III. Spiritual perspective

\begin{tabular}{lr} 
Statements & Average \\
\hline A disability or chronic illness can change a person's reality of work & 4.07 \\
Given the physical characteristics, some activities are best developed & 3.44 \\
by women than by men, and vice versa & 3.75
\end{tabular}

Source: Prepared by the authors

Table IV. Physiological perspective 
REGE 25,1

Table V.

Ideological perspective Source: Prepared by the authors participated in our research: another respondent:

Statements
The first respondent, for example, highlights the "class fight" and dialogues with the socialist thinking, while the second brings elements of a neoliberal line of thinking when pointing entrepreneurship and its possible implications to the sense of work.

With regards to the ideological perspective, we reproduce the statement of a banker who

I believe ideologies are the trigger for behavior at work. But the depending of a salary as a means of survival implies you will submit to what is imposed to you, up to the limit of your tolerance. For example, If I don't like to charge a client and I believe this is wrong, but work demands that I do it regardless, under the penalty of losing this job, I "force myself to charge". However, if work demands that I "steal" from someone, I'd rather go away, because it is beyond my dogma's tolerable limit. I believe we are hostages of a general labor and social relation system. Some choose not to see, others don't see, others see and do nothing and others try to stand, but always within the limits of how much you depend or not on your salary as your means of survival.

The question about power relations at work raised the following thought, by

In the statement "organizations can exercise a power/domination (bondage/submission) relation with those working on it", I believe the organizations do it quietly, making worker feel like they must obey the rules imposed while fearing they would lose their jobs if they don't. They say you must "collaborate" and "take one for the team", do more than what they pay you to do, but they will fire you without giving it a second thought, without considering the employee's needs.

Table VI regards the political perspective and presents a general average of 4.28. Among the indicators evaluated, the one presenting the highest concordance average (4.44) was: work somehow organizes the functioning of society. Occasionally, in this statement, agreeing with the authors, one of the respondents stressed that "the other way around is true" and that "the way society functions also organizes work." Another participant of the research complemented:

I believe that work, or rather what we produce is what gives meaning to our existence as human beings. However, the current forms of work seem to do a disfavor, for the most part, to the creative development and an effective relationship with what is produced, usually creating a relationship of alienation between the worker and the object of his/her work. I believe people end up wasting their powers, having to fit within pre-established standards, in relations of submission or estrangement.

Average

The way a person sees the world can reflect in the way he/she perceives the job

An idealized reality can camouflage the real way in which the work presents itself

A person whose ideology is more linked to socialism or communism will see labor relations differently from a person whose ideology is more linked to liberalism or capitalism

Overall average of this perspective

4.22
Statements

Work somehow organizes the functioning of society Organizations can exercise a power/domination (bondage/submission) relation with those working on it Overall average of this perspective

Table VI.

Political perspective
Source: Prepared by the authors
Average 
Under the legal perspective, the average perceived was 4.01. Among the indicators evaluated, the one presenting the highest concordance average (4.39) was: in Brazil, many social rights are connected with work (e.g. FGTS, PIS, unemployment insurance). As per Table VII, even perceiving the loss of labor rights, it is important to pay attention that the respondents considered this statement as an important dimension in their lives, admitting that the search for the formal labor market is important. Different positions and opinions like "the CLT (Brazilian Consolidation of Labor Laws) should be more flexible in some matters and updated in some items, like Home Office, for instance, labor time agreements, etc." and "I suggest more windows to discuss the informal job of freelancers, something that has been increasing in Brazil and in the world, and how it will impact the older years of the people who are young nowadays, after all, this modality of work does not include social rights" appeared in this survey. These statements can be interpreted as an increasing need to know labor alternatives, in a market where contracts become more and more flexible. There is a certain resilience in the perception of the traditional model of labor relations and, as a result, people feel the need to understand the changes and what they achieve in their professional lives, now and in the future.

Under the psychosocial perspective, the average perceived was 4.25. Table VIII shows that, among the indicators evaluated, the one presenting the highest concordance average (4.47) was: work is a connection with society, with other people, and is an important means to a broad contact network. The reference to how central work is in the subjects' lives and development is made clear by this statement. In addition, it can be assumed that the respondents are inferring the importance of the contact and relationship network, as both maintain employability/workability. Therefore, work continues to represent an important space in everyone's life. One of the respondents agrees and makes the following statement: "work itself makes you useful and allows you to grow as a human being."

Two questions were made to check if, when answering this survey, the perception about work would change. The question: "Do you agree with the statement that work needs to be seen from different perspectives," placed at the beginning of the questionnaire, had an average of 4.31. The question: "do you believe work can have different interpretations depending on the perspective from which it is analyzed?", placed at the end of the questionnaire, presented an average of 4.51, i.e., superior to the first question. Therefore,

Statements

Average

In Brazil, many social rights are connected with work (e.g. FGTS, PIS, unemployment insurance) There are differences between meaning and sense of labor depending on how (formally or informally) the worker is hired

Overall average of this perspective

Source: Prepared by the authors

Table VII.

Legal perspective

Statements

Average

Work is a connection with society, with other people, and is an important means to a broad contact network

Work represents a lot about people's lives

To what extent do you consider work as something central in your life?

Overall average of this perspective

Source: Prepared by the authors

Table VIII.

Psychosocial perspective 
REGE

25,1

76

Figure 2.

General averages of work perspectives at the end of the survey, it was noticed that the respondent has extended his/her perception about work, understanding it more plural than the first.

Some comments further explain the quantitative data discussed: "the survey carried out suggests reflecting on the human being and his/her relation with the work force. I liked it!" "these questions are practically 'suggestive' to the reader, to make him/her realize ideas, even those unnoticed, about work," "I liked answering to this survey, for it has very interesting questions, which makes us think what really is work."

It is concluded that there has been an increase in the perception of work as multifaceted after participating in this research. There is an average correlation $(r=0.47)$ between the prospects considered in this study, showing margin error of 0.0 percent. As assumed, we can say that work is a phenomenon that must be analyzed from multiple perspectives.

Finally, Figure 2 highlights the cultural perspective as having the highest value of agreement for respondents, that is, from all perspectives, the responses of cultural dimension were the ones that presented the most present sense of respondents.

\subsection{Order of importance of work perspectives}

In Table IX, we have the first columns without gender differentiation, in which the physiological perspective emerges in first place as influence, followed by legal and spiritual dimensions. The economic point of view, ranked fourth in importance, contradicts the literature that relates work only to the economic factor and as a synonym for labor.

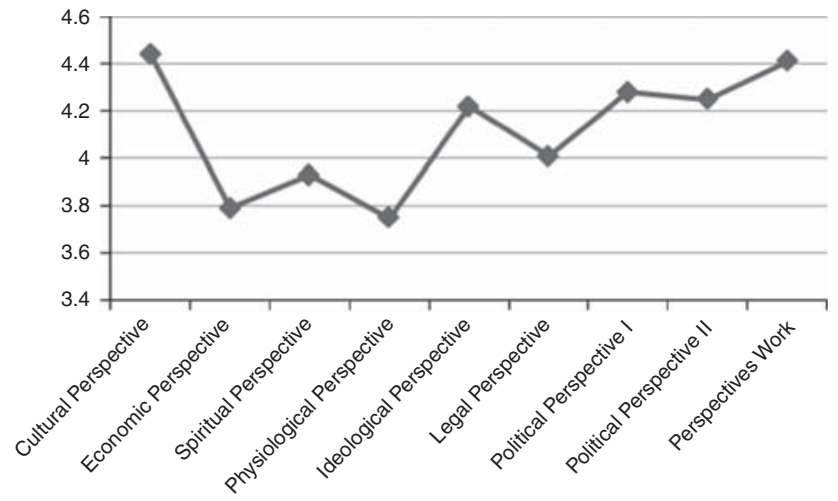

Source: Prepared by the authors
Table IX.

Regression - order of importance of work perspectives

\begin{tabular}{lclclcc}
\hline Perspective & $\beta$ & $\begin{array}{l}\text { General } \\
\text { Order }\end{array}$ & $\beta$ & $\begin{array}{l}\text { Male } \\
\text { Order }\end{array}$ & $\beta$ & $\begin{array}{l}\text { Female } \\
\text { Order }\end{array}$ \\
\hline Physiological & 0.246 & 1st & 0.245 & 2nd & 0.246 & 1st \\
Legal & 0.221 & 2nd & 0.220 & 4th & 0.220 & 2nd \\
Spiritual & 0.249 & 3rd & 0.282 & 1st & 0.219 & 3rd \\
Economic & 0.213 & 4th & 0.230 & 3rd & 0.198 & 4th \\
Ideological & 0.179 & 5th & 0.178 & 6th & 0.180 & 5th \\
Cultural & 0.154 & 6th & 0.151 & 7th & 0.156 & 6th \\
Psychosocial & 0.172 & 7th & 0.197 & 5th & 0.150 & 7th \\
Political & 0.123 & 8th & 0.117 & 8th & 0.128 & 8th
\end{tabular}

Source: Prepared by the authors 
Subsequently, the Table IX columns were separated so that they could infer whether gender has any impact on the importance given to the perspectives presented. A Beta distinction can be verified between the groups. Women tend to assign greater influence to the physiological perspective in the perception of the work. This factor may be related to the fact that they are the most vulnerable in the gender division of labor and also - culturally - responsible for taking care of elderly and children. Women also give great importance to the legal dimension of work, possibly because of their fight for rights and opportunities equality in the work environment, which have not yet been fully achieved.

In this point, the survey transformed into a whistleblowing vehicle, when a woman who works as a saleswoman, without labor bond, used this space to warn: "there are many women doing the same work as men and making less money." The same occurred with the suggestion of a lawyer: "there should be a question approaching wage difference between men and women."

Male workers are those who give more importance to the spiritual perspective, in the overall perception of work. This is, according to Table IX, when compared with women, men attributed more importance to psychosocial and economic dimensions. Among the eight perspectives mentioned, politics was overall the one with the lowest representativeness in the perception of work. One could question whether this result would be connected to the alienation of workers, which would not have conscience about the dominance and submission present in the working environment, as well as to what extent work is a social organizer. Or, on the contrary, for the conscience that workers have obtained about all this, as a result of the greater availability of information and greater political participation. Or even by the realization that the political situation regarding employment right now is inescapable, denoting disappointment or discouragement with the social struggles. It would be necessary to obtain more information about these issues to decide which of the alternatives would be more consistent with the perception of respondents.

In general terms, Table IX shows the order of importance of the perspectives on work, from the point of view of the respondents: physiological perspective, then legal, spiritual, economic, ideological, cultural, psychosocial and political perspectives. Working in a situation of formality or informality seems to have not influenced this choice. However, on analyzing the questions related to legal perspective of this survey, it was noticed that for the statement: In Brazil, many social rights are connected with work (e.g. FGTS, PIS, unemployment insurance), there was interference with 14 percent margin of error, that is, there is a correlation. For the statement: There are differences between meaning and sense of labor depending on how (formally or informally) the worker is hired, there is a 96 percent certainty that there is no difference in perception between formal and informal workers.

It is noticed that men and women attribute different importance to the perspectives, i.e., when considering these points of view, men highlight the spiritual perspective of work, while women consider physiological matters. The age and schooling also influenced the perception of some dimensions of the work, as we see in Table X.

The age factor interfered with how cultural, legal and political perspectives were perceived. Being that the respondents between 26 and 35 years have a greater degree of concordance with the cultural dimension, with respect to the influence of the social heritage

\begin{tabular}{lccccr}
\hline Age & Up to 25 years & 26-35 years & 36-45 years & Over 45 years & Sig. \\
\hline Cultural & 4.4486 & 4.5314 & 4.3414 & 4.2624 & 0.022 \\
Legal & 3.9393 & 4.0382 & 3.8855 & 4.2979 & 0.039 \\
Political & 2.7321 & 2.8902 & 2.9197 & 2.8652 & 0.027
\end{tabular}

Source: Prepared by the authors

\section{Integrating perspectives}

(1)


REGE 25,1

78

in the world of labor. At its turn, the legal perspective presents a greater degree of concordance among people older than 45 years. It can be assumed that these people are more aware of the importance of their labor rights, among other factors, for their longer professional history and possibly being closer to retirement. On analyzing the statements, we get Table XI.

Table XI considers only responses that have had a significance level of up to 0.05 . Regarding the analysis between differences in perceived averages in relation to age, it can be said that a greater degree of concordance prevails in the age group of up to 25 years, a lesser degree of concordance from 36 to 45 years and a greater regularity in the responses from 26 to 35 years. For example, for the statement: A person's world view can reflect the way he/she perceives work, considering 4.65 as a numeric value, the highest averages were verified in the ranges of up to 25 years and from 26 to 35 years.

In the political perspective, concerning the matter: Organizations can exercise a power/domination (bondage/submission) relation with those working on it, the highest level of concordance was 4.33, in the range from 26 to 35 years. We can associate this result with what Sennett (2009) said about repression, power and control, being reasonable to infer that the young people of this age group are more discerning about the mechanisms of power and subordination exercised by organizations on their employees.

In the legal dimension, the fact that the highest level of concordance has been expressed in the responses of people aged over 45 years (4.62) draws attention. Analyzing the legal dimension of the job is also bringing into discussion what refers to its formal and informal character. In the formal character, for example, is the concept used to denote the worker who is officially registered, showing proof of employment. The informal dimension concerns the low or inexistent formalization, whether of the activity itself, whether of the forms of labor insertion. One might think, therefore, from the data obtained, that the greater the age, the greater the certainty that social rights are associated with the job and that there is the desire to possess them.

Additionally, for the statement: work represents a lot to people's lives, also obtained higher level of concordance for the age group over 45 years - 4.66 - which is considered a high value. This question refers to the psychosocial dimension of work that posits, in general terms, that work means recognition, gratitude, constitution of identity and subjectivity, as well as social bond (Clot, 2007; Dejours, 2004). This question allows to infer that questions relating to the sense and meaning of work, as a means of social and individual achievement, may have greater significance for people over the age of 45 .

\begin{tabular}{|c|c|c|c|c|c|}
\hline Indicators & $\begin{array}{l}\text { Up to } 25 \\
\text { years }\end{array}$ & $\begin{array}{l}26-35 \\
\text { years }\end{array}$ & $\begin{array}{l}36-45 \\
\text { years }\end{array}$ & $\begin{array}{c}\text { Over } 45 \\
\text { years }\end{array}$ & Sig. \\
\hline $\begin{array}{l}\text { The way a person sees the world can reflect in the way he/she } \\
\text { perceives the job (ideological perspective) }\end{array}$ & 4.65 & 4.65 & 4.39 & 4.13 & 0.001 \\
\hline $\begin{array}{l}\text { Religion can change the way someone perceives work } \\
\text { (spiritual perspective) }\end{array}$ & 4.08 & 4.00 & 3.93 & 3.43 & 0.001 \\
\hline $\begin{array}{l}\text { Organizations can exercise a power/domination (bondage/ } \\
\text { submission) relation with those working on it (political perspective) } \\
\text { In Brazil, many social rights are connected with work (e.g. FGTS, }\end{array}$ & 3.69 & 4.33 & 4.19 & 4.19 & 0.000 \\
\hline PIS, unemployment insurance) (legal perspective) & 4.23 & 4.41 & 4.43 & 4.62 & 0.054 \\
\hline Work represents a lot to people's lives (psychosocial perspective) & 4.41 & 4.24 & 4.47 & 4.66 & 0.005 \\
\hline $\begin{array}{l}\text { Having a wage is a way to feel safe, organize life, project a future } \\
\text { and have the expectancy that your children will climb up the } \\
\text { social ladder (economic perspective) }\end{array}$ & 4.62 & 4.28 & 4.42 & 4.49 & 0.010 \\
\hline Source: Prepared by the authors & & & & & \\
\hline
\end{tabular}

Table XI.

Indicators: averages according to age

Source: Prepared by the authors

The way a person sees the world can reflect in the way he/she perceives the job (ideological perspective) (spiritual perspective)

Organizations can exercise a power/domination (bondage/ submission) relation with those working on it (political perspective) PIS, unemployment insurance) (legal perspective) Work represents a lot to people's lives (psychosocial perspective) Having a wage is a way to feel safe, organize life, project a future and have the expectancy that your children will climb up the 
Maybe the sentence written by Dejours (2004, p. 18) "working is not solely producing: working is still living together," makes more sense for workers over 45 years.

Finally, the statement: having a salary is a way to feel safe, organizing life, designing a future and having expectations for your children to climb up the social ladder, had the highest relative average value in the age group up to 25 years (4.62). This fact draws attention, since it concerns the economic perspective. Under this perspective, work regards financial gains and more possibility of consuming. Deepening the investigation of the sense of work for different generations would be interesting.

Following the analysis and respecting the significance values lower than 0.05 , Table XII presents the average of numeric values, in relation to scholarship and the questions that regard the physiological, cultural, economic and political perspectives. It is noteworthy that all values with higher concordance were reached by respondents who are post-graduates. Such a fact can be associated both to the understanding of the matter, and to its meaning for the respondent, or also if there is significant relationship between the degree of education and the perception on the meaning of work.

The results contained in Table XIII suggest that people with higher education have a higher level of concordance with the cultural, ideological and political perspectives.

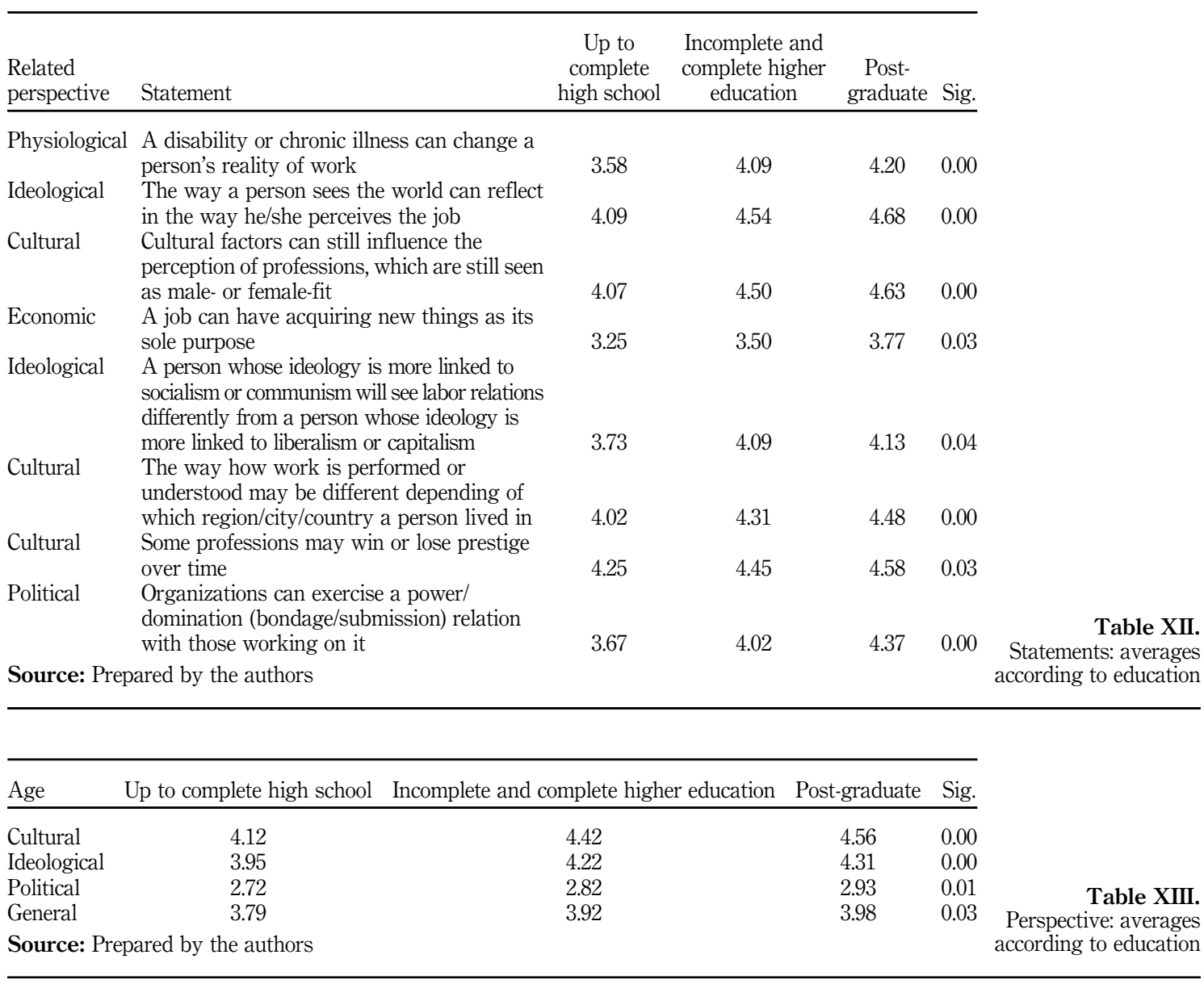


REGE

25,1

Particularly for cultural, the highest level of concordance was reached. Elements, such as region, gender and status, concern the cultural perspective. That is, depending on the region where the respondent lives or was raised, or still, where the respondent works, the phenomenon work can be perceived, developed and valued differently. Unfortunately, the same can happen, depending if the respondent is a man or a woman. Likewise, depending on regional characteristics, a profession can have higher or lower status. Thus, depending on education, people tend to have more freedom to designate the future of their personal and professional lives, whereas people with lower level of education tend to be more frequently submitted to the rules of the labor market. The vision of the world and how it influences work also had higher level of concordance among people with a higher level of education, which can mean sharper political perceptions, especially about submission and organization of work in society.

With a high level of trust, we can affirm how education interferes with the perception of the cultural, ideological and political dimensions of the phenomenon of work. As well as the perception that work can and must be interpreted under different perspectives. It is stressed, overall, that the group classified as Post-Graduate or Post-Graduate Student presented a higher level of concordance in all perceptions, except only physiological and psychosocial dimensions. One can infer that this group has a more solid position and more critical look regarding gender matters and how central work is in their lives.

Also, the 407 respondents indicated 884 occupations considered by them as more "malefit." To facilitate analysis, the occupations were grouped into 25 areas. Thus, the occupations considered as male-fitter are, predominantly, in the area of civil construction (52.1 percent), followed by professions connected to transport (36.4 percent) and strength (17.2 percent). Also, it specified that areas such as Engineering (16 percent), maintenance (13.5 percent) and security (13 percent) as mostly associated with men. As for occupations designated as "female-fit," researchers pointed 727 occupations that were distributed into 15 categories. Esthetics (21.6 percent) and domestic (20.4 percent)-related activities were those that received the highest number of attributions, and the administrative area ranked third, with 18.9 percent. Health-related professions (18.4 percent), caregiving (17 percent) and education (12.8 percent) were also given prominent positions. Thus, it is noticed that gender-division of labor is still quite present in society, that is, the gender is still a social marker, which influences significantly the activities that will be developed by different genders. However, it is stressed that about 10 percent of the respondents did not agree to mention professions and occupations/activities that were fitter to one sex or the other.

\section{Conclusions and recommendations}

From the analysis of the data collectively collected, it was realized that work cannot be seen from a single perspective, but it must be seen in its multifaceted character and sense. The application of a survey was important to analyze that several perspectives, as well as to give the respondents, through alternative answers on the several items, an extension of the ways to understand the sense of work.

The items in the questionnaire allowed looking at the senses of work from the physiological perspective and so think how much important for work is the "biological machine." The legal dimension appeared important to respondents, despite the growing awareness of the loss of labor rights in Brazil. The cultural dimension was relevant to people, with regard to the status of the profession, to perceptions about aging, the gender division of labor and other aspects socially defined and reproduced. The economic perspective stood out as a dimension of work connected to income and support of consumer desires, professional growth and status in our society. The ideological one, at its turn, proved to be due to the tendency to reproduce our worldview at work. As for the spiritual, the religion or spirituality itself influences on the drive and the structuring of collective or 
individual organizations, and how people may face the labor activity and to transcend a purely utilitarian vision of the work phenomenon. Finally, the political perspective intrinsically organizes our lives around work.

If work was considered punishment, due to the very meaning of the word, currently it earns a much more significant and symbolic look. Therefore, you cannot reflect on work without thinking of subjectivity, without relating that we are bio-psycho-social-spiritual beings and that work is important in the constitution of who we are. Also, one cannot minimize the role of the organizations, which are part of our society, of their social interactions and relations of power. In addition, for different people in different stages of their lives, work can vary from needs restricted to survival, going through the fight for recognition, until maybe reaching self-realization. This road is not unique, much less rectilinear. These elements together form what we call the sense and meaning of work.

The main contributions of this article are, on the one hand, the effort of synthesis and record of eight categories of analyzing multiple and possible senses of work, developed through review of the literature. On the other hand, is the pursuit of understanding and analysis of these categories, by means of a numerically significant public perception, not limited and with different backgrounds. This study was a process that produced many insights on the theme, however and foremostly, it provided an interactive and non-unilateral apprenticeship between interviewers and interviwees, on the meanings and values of work. This was one of the most astonishing and rewarding results of the study.

It should be noted that, for data surveys, social networks have been an interesting source of approaching the field. However, even though this is a diverse sample, it is suggested to use other channels to obtain data, for future researches. The virtual environment is useful and limiting at the same time, especially because the data sources are limited to how much people know and can write about what they think. At the end of this trajectory, we consider that a single form of collection, especially by means of writing, limits the amplitude of data, in addition to raising interpretation doubts regarding the content of the answers, aggravated by the impossibility of face-to-face clarifications. We know that this can be verified in all forms of access to data and, for this reason, we suggest, in future research related to the theme, the association of different data-collection techniques. It is also suggested to evaluate field observation in a larger integration between quantitative and qualitative researches.

It is also expected - for the researchers who prefer so - that this paper can serve as a guide in future research so that - when the phenomenon work is approached - it can more consciously choose or know from which point(s) of view or perspective(s) will be they be performing their analysis. We finish expecting that this study is a propeller of increasing continuity and incentive for researches on this theme, which is so relevant for all people and so central in our society, since always and for always.

\section{References}

Antunes, R. (2002a), Os sentidos do trabalho: ensaio sobre a afirmação e negação do trabalho, Boitempo, São Paulo.

Antunes, R. (2002b), Adeus ao trabalho? Ensaio sobre as metamorfoses e a centralidade do mundo do trabalho, Editora Unicamp, Campinas.

Barel, Y. (1982), La marginalité sociale, PUF, Paris.

Bastos, A.V.B., Pinho, A.P.M. and Costa, C.A. (1995), "Significado do trabalho: um estudo entre trabalhadores inseridos em organizações formais", Revista de Administração de Empresas, Vol. 35 No. 6, pp. 20-29.

Bauman, Z. (2005), Vite di Scarto, Laterza, Bari.

Bauman, Z. (2007), Vida líquida, Jorge Zahar Editor, Rio de Janeiro. 
REGE 25,1

Becker, H.S. (2008), Outsiders: estudos de sociologia do desvio, Zahar, Rio de Janeiro.

Bendassoli, P.F. (2009), Psicologia e trabalho: apropriações e significados, Cengage Learning, São Paulo.

Carreteiro, T.C. (2006), "O trabalho na vida do jovem: perspectivas diferentes", Grupo de pesquisa Observatório Jovem, Rio de Janeiro, [entrevista], available at: www.uff.br/observatoriojovem/ materia/o-trabalho-na-vida-do-jovem-perspectivas-diferentes (accessed March 14, 2016).

Cattani, A.D. and Holzmann, L. (2011), Dicionário de trabalho e tecnologia, 2nd ed., Editora Zouk, Porto Alegre.

Castel, R. (1998), As metamorfoses da questão social: uma crônica do salário, Vozes, Petrópolis.

Clot, Y. (2007), A função psicológica do trabalho, Vozes, São Paulo.

Dejours, C. (2004), Da psicopatologia à psicodinâmica do trabalho. Tradução Franck Soudant. Organizadores: Selma Lancman e Laerte Idal Sznelwar, Fiocruz, Rio de Janeiro.

Dejours, C., Abdoucheli, E. and Jayet, C. (2012), Psicodinâmica do trabalho, contribuições da escola Dejouriana à análise da relação prazer, sofrimento e trabalho, Coordenação: Maria Irene StoccoBetiol, Atlas, São Paulo.

Dourado, D.C.P., de Holanda, L.A., da Silva, M.M.M. and de Araújo Bispo, D. (2009), "Sobre o sentido do trabalho fora do enclave de mercado", Cadernos Ebape. BR, Vol. 7 No. 2, pp. 349-367.

Duncan, C. and Loretto, W. (2004), "Never the right age? Gender and age-based discrimination in employment", Gender, Work and Organization, Vol. 11 No. 1, pp. 95-115.

Etzioni, A. (1964), Modern Organizations, Foundations of Modern Sociology Series, New Jersey, NJ.

Fontoura, S. and Rocha-De-Oliveira, S. (2014), "A construção social do(s) Mercado(s) de Trabalho: espaços de lutas de Classe, Gênero e Idade", VIII Encontro de Estudos Organizacionais da ANPAD - ENANPAD, Gramado.

Giddens, A. (2002), Modernidade e identidade, Jorge Zahar Editor, Rio de Janeiro.

Hirata, H. and Kergoat, D. (2007), "Novas configurações da divisão sexual do trabalho", Tradução: Fátima Murad. Cadernos de Pesquisa, Vol. 37 No. 132, pp. 595-609.

Holzmann, L. (2011), "Divisão social do trabalho”, in Cattani, A.D. and Holzmann, L. (Eds), Dicionário de trabalho e tecnologia, 2nd ed., Editora Zouk, Porto Alegre.

Horochovski, R.R. and Taylor, C.R. (2001), "A estruturação do sujeito nas instituições e organizações: aspectos inconscientes no cotidiano organizacional”, Revista Spei, Vol. 2 No. 2, pp. 37-47.

Krishnakumar, S. and Neck, C.P. (2002), "The 'what', 'why' and 'how' of spirituality in the workplace”, Journal of Managerial Psychology, Vol. 17 No. 3, pp. 153-164.

Laner, A.S. (2005), Psicologia e trabalho na história: da apropriação do tempo à busca da felicidade, Unijuí, Ijuí.

Lima, O.B.A., Lopes, M.E.L., Carvalho, G.D.A. and Melo, V.C. (2012), O idoso frente ao processo de envelhecimento: produção científica em periódico online no âmbito da Saúde, Trabalho submetido ao $15^{\circ}$ Congresso Brasileiro dos Conselhos de Enfermagem (CBCENF). Eixo Temático - Determinantes de Vida e de Trabalho.

Locatelli, P.A.P.C. and Dos Santos Fontoura, D. (2013), "Envelhecimento populacional e os estudos em administração", Gestão e Sociedade, Vol. 7 No. 17, pp. 273-300.

Marques, L.F. (2010), O conceito de espiritualidade e sua interface com a religiosidade e a Psicologia Positiva, Psicodebate, Buenos Aires, Vol. 10, pp. 135-151.

Mercure, D. and Spurk, J. (2005), O trabalho na história do pensamento ocidental, RJ: Vozes, Petrópolis. 
Mises, L.V. (1995), Ação Humana: um tratado de economia, Tradução de Donald Stewart Jr, Instituto Liberal, Rio de Janeiro.

Morin, E.M. (2001), "Os sentidos do trabalho. Revista de Administração de Empresas - RAE", São Paulo, Vol. 41 No. 3, pp. 8-19.

Mow (1987), International Research Team, Academic Press, Londres.

Presthus, R. (1962), The Organizational Society, Knopf, New York, NY.

Rifkin, J. (2007), La fine del lavoro: il decline della forza lavoro globale e l'avvento dell'era post-mercato, Oscar Mondadori, Milano.

Rodrigues, A.L. and Barrichello, A. (2015), "Em busca da substantivação do conceito de sentidos do trabalho: um estudo com profissionais de enfermagem", XXXIX ENANPAD, Belo Horizonte, pp. 1-17.

Rodrigues, M.B. (2014), “Trajetórias de vida e de trabalho flexíveis: o processo de trabalho pós-Braverman”, Cad. EBAPE, Vol. 12 No. 4, pp. 770-788.

Sennett, R. (2009), A corrosão do caráter: consequências pessoais do trabalho no novo capitalismo, 14th ed., Record, Rio de Janeiro.

Schlindwein, V.L.D.C. (2013), "Histórias de vida marcadas por humilhação, assédio moral e adoecimento no trabalho", Psicologia \& Sociedade, Vol. 2 No. 25, pp. 430-439.

Souza, R.M.B. and Tolfo, S.R. (2009), "Significados atribuídos ao trabalho em condições precárias: um estudo com feirantes do largo da ordem de Curitiba", Anais, XV Encontro da ABRAPSO, Curitiba, Paraná.

Spinelli-De-Sá, J.G. and Lemos, A.H.C. (2015), "Sentido do trabalho: uma Análise da Produção Científica Brasileira”, XXXIX ENANPAD, Belo Horizonte, pp. 1-20.

Tozatto, M.I. (2009), "Feridas no tecido familiar", XVIII Congresso Latino-Americano FLAPAG e X Simpósio CEFAS. Práticas Institucionais na América Latina: Casal, Família, Grupo e Comunidade, São Paulo.

\section{Further reading}

Albornoz, S. (2006), O que é trabalho, Brasiliense, São Paulo.

Bendassoli, P.F. (2007), Trabalho e identidade em tempos sombrios: insegurança ontológica na experiência atual com o trabalho, Ideias \& Letras, Aparecida.

Dejours, C. (2015), "Subjetividade, trabalho e ação", Revista Produção, Vol. 14 No. 3, pp. 27-34, available at: www.scielo.br/pdf/\%0D/prod/v14n3/v14n3a03.pdf

Fontenelle, I.A. (2014), O estatuto do consumo na compreensão da lógica e das mutações do capitalismo, Vol. 1, Lua Nova, São Paulo, pp. 207-240.

Silva, E. (1982), Trabalho em turnos alternados e saúde mental, Comunicação à Reunião da SBPC, Campinas.

Zohar, D. (2012), Spiritual Intelligence: The Ultimate Intelligence, Bloomsbury Publishing Group, London.

\section{Corresponding author}

Renato Koch Colomby can be contacted at: renato.colomby@gmail.com

For instructions on how to order reprints of this article, please visit our website:

www.emeraldgrouppublishing.com/licensing/reprints.htm

Or contact us for further details: permissions $@$ emeraldinsight.com 